\title{
TINDAK TUTUR NGGAHI PANATI DALAM PROSESI LAMARAN PERNIKAHAN ADAT BIMA: SUATU KAJIAN PRAGMATIK SERTA IMPLIKASINYA DALAM PEMBELAJARAN MULOK DI SEKOLAH
}

Universitas Mataram irham201@yahoo.com

\begin{abstract}
Abstrak
Ada tiga aspek kebermaknaan tindak tutur Nggahi Panati dalam prosesi lamaran pernikahan adat Bima, yaitu bentuk tindak tutur, aspek kerja sama, dan aspek kesantunan. Penelitian ini bertujuan mengetahui kebermaknaan tindak tutur Nggahi Panati dalam prosesi lamaran pernikahan adat Bima serta implikasinya terhadap pembelajaran muatan lokal bahasa daerah di sekolah. Hasil penelitian menunjukkan bahwa bentuk tindak tutur Nggahi Panati berkategori representatif (menyatakan, menyebutkan, dan melaporkan), berkategori direktif (memohon, meminta, dan mengajak), berkategori ekspresif (memuji, menyanjung, dan berterima kasih), kategori komisif (berjanji dan menyatakan kesanggupan), dan berkategori deklaratif (mengabulkan dan memutuskan). Hasil penelitian menyimpulkan pula bahwa aspek kerja sama dan aspek kesantuanan dalam tindak tutur Nggahi Panati sangat diperhatikan dan diutamakan oleh penutur dan mitra tutur dalam bertutur. Selain penggunaan idiom, penutur dan mitra tutur menggunakan pula pantun dan bahasa metafora.
\end{abstract}

Kata kunci: Tindak tutur Nggahi Panati, lamaran pernikahan adat Bima, kajian pragmatik

\begin{abstract}
There are three aspects of the meaningfulness of speech acts Nggahi Panati in procession Bima customary marriage proposal, namely the form of speech acts, cooperation aspects, and aspects of politeness. This study aims to determine the significance of the speech act in a procession Nggahi Panati Bima customary marriage proposal and its implications for the learning of local content in local language school. The results showed that the form of speech act category Nggahi Panati representative (states, states, and reporting), categorized directive (beg, ask, and urge), expressive category (praise, laud, and grateful), category commissive (promise and declare readiness), and categorized declarative (grant and decide). The study concluded also that aspects of cooperation and aspects of speech acts Nggahi Panati in politeness very considered and prioritized by the speaker and hearer in speaking. In addition to the use of idioms, speaker and hearer using rhymes and language metaphor anyway.
\end{abstract}

Keywords: Speech acts of Nggahi Panati, custom wedding proposal Bima, pragmatic study

\section{PENDAHULUAN}

Bahasa tidak hanya berfungsi sebagai alat komunikasi tetapi juga sebagai media untuk melakukan tindakan dan cerminan budaya. Hal ini dapat dilihat dari konsep langue dan parole. Langue adalah totalitas fakta kebahasaan yang oleh Saussure disebut produk sosial yang tersimpan di dalam pikiran penutur. Sedangkan parole adalah ujaran yang diproduksi oleh penutur. Parole hanya dapat dipahami melalui pengkajian terhadap langue. Keterikatan antara bahasa dengan budaya juga diungkapkan oleh Boas (dalam Oktavianus, 2006:5) yang menyatakan bahwa adanya saling pengaruh yang dinamis tidak hanya antara bahasa dan pikiran, melainkan juga bahasa dengan adat istiadat, perilaku suatu etnis dan perubahan- 
perubahan yang terjadi dalam budaya. Bagi setiap etnis, bahasa daerah mempunyai peranan yang sangat penting. Selain berfungsi seperti bahasa pada umumnya, yaitu alat komunikasi dalam masyarakat penuturnya, bahasa daerah juga berfungsi sebagai lambang kebanggaan daerah dan lambang identitas daerah. Begitu pula halnya dengan bahasa Bima.

Bahasa Bima atau Nggahi Mbojo merupakan salah satu bahasa daerah yang terdapat di Indonesia yang memiliki kaidahkaidah penggunaannya. Kaidah penggunaan bahasa Bima ini bila ditinjau dari variasi bahasa yang digunakan oleh penuturnya, ada yang menggunakan variasi bahasa tinggi atau Nggahi Mangame dan ada pula yang menggunakan variasi bahasa rendah atau Nggahi Nginakai. Pembedaan variasi bahasa (variasi bahasa tinggi dan bahasa rendah) ini menurut Ferguson (1964, dalam Chaer, 2003:62) disebut diglosia.

Penggunaan variasi bahasa tinggi atau Nggahi Mangame biasanya digunakan pada konteks tuturan dengan latar belakang pengetahuan yang dipahami bersama oleh penutur dan mitra tutur, seperti penggunaannya dalam prosesi lamaran pernikahan adat Bima yang disebut Panati. Bahasa yang digunakan dalam prosesi lamaran pernikahan ini berbeda dengan bahasa yang digunakan dalam komunikasi sehari-hari, sehingga dalam adat budaya Bima dikenal dengan istilah Nggahi Panati atau bahasa lamaran.
Bahasa yang digunakan dalam Nggahi Panati biasanya dituturkan dengan ungkapan atau idiom selain tuturan yang umum dalam komunikasi sehari-hari. Seperti ungkapan Mada ne'e midi dei loko ita doho; arti secara harafiah dalam bahasa Indonesia adalah 'Saya ingin tinggal dalam perut anda sekalian (bapak dan ibu calon mertua)'. Ungkapan ini bermakna 'melamar' atau 'pernyataan lamaran' dari seorang jejaka/ pria yang ditujukan kepada orangtua gadis yang ingin dilamar.

Penggunaan ungkapan atau idiom dalam tindak tutur Nggahi Panati berfungsi untuk memperhalus maksud dengan mengutamakan adab kesantunan berbahasa. Tujuannya, agar maksud dari pembicaraan tersebut tercapai atau terjadi kesepakatan sesuai makna konteksnya. Makna konteks tersebut dilihat dari pemahaman bersama antara penutur dan lawan tutur atau pendengar sehingga tujuan bertutur menjadi komunikatif. Dengan demikian, bila dicermati ada tiga aspek kebermaknaan (mengandung makna dan fungsi komunikatif) dalam tindak tutur Nggahi Panati terkait penggunaan ungkapan atau idiom, yaitu bentuk tindak tutur, aspek kerja sama, dan aspek kesantunan.

Tindak tutur Nggahi Panati dalam prosesi lamaran pernikahan adat Bima ini menarik untuk diteliti dan dikaji dari sudut pandang pragmatik. Hal ini merujuk pada pernyataan yang dikemukakan oleh Levinson (dalam Nababan, 1987:2), bahwa pragmatik memiliki dua pengertian. Per- 
tama, kajian dari hubungan antara bahasa dan konteks yang mendasari penjelasan pengertian bahasa. Kedua, kajian tentang kemampuan pemakaian bahasa mengaitkan kalimat-kalimat dengan konteks-konteks yang sesuai bagi kalimat-kalimat itu.

Kajian pragmatik terhadap tindak tutur Nggahi Panati dalam prosesi lamaran pernikahan adat Bima ini merupakan salah satu bentuk penelitian penggunaan bahasa Bima dalam masyarakat penuturnya sebagai upaya untuk merevitalisasi Nggahi Mbojo (bahasa daerah) yang akhir-akhir ini mulai "tersisihkan" oleh penggunaan bahasa Indonesia dan bahasa asing. Sebagai wujud merevitalisasi Nggahi Mbojo ini yakni dengan cara mengimplementasikannya ke dalam pembelajaran di sekolah melalui pembelajaran muatan lokal (Mulok) bahasa daerah.

Berdasarkan uraian di atas, maka penelitian ini bermaksud untuk mengkaji tindak tutur Nggahi Panati dalam prosesi lamaran pernikahan adat Bima dari sudut pandang pragmatik, dengan memfokuskan masalah penelitian pada kebermaknaan tindak tutur Nggahi Panati dalam prosesi lamaran pernikahan adat Bima. Sedangkan hasil kajian dari penelitian ini diimplikasikan ke dalam pembelajaran mulok bahasa daerah di sekolah.

\section{KONSEP DAN KERANGKA TEORI}

\section{Kerangka Teori}

Istilah pragmatik diperkenalkan oleh seorang filosof yang bernama Charles Mor- ris tahun 1938, ketika ia membicarakan bentuk umum ilmu tanda (semiotik). Ia menjelaskan (dalam Levinson, 1983:1) bahwa semiotik memiliki tiga bidang kajian, yaitu sintaksis (syintax), semantik (semantics), dan pragmatik (pagmatics). Sintaksis (syntax) mempelajari hubungan antara tanda dengan tanda yang lain; semantik (semantics) mempelajari hubungan antara tanda dengan objek yang diacu oleh tanda; dan pragmatik (pragmatics) mempelajari hubungan antara tanda dan penggunanya.

Leech (1993:9) menyatakan bahwa pragmatik adalah studi tentang makna dalam hubungannya dengan situasi ujar (speech situations). Pragmatik diperlukan untuk menganalisis makna yang dipertuturkan antara penutur dan mitra tutur yang disesuaikan dengan situasi ujar. Sementara Verhaar (1996:14) menjelaskan bahwa pragmatik merupakan cabang ilmu linguistik yang membahas tentang apa yang termasuk struktur bahasa sebagai alat komunikasi antara penutur dan pendengar, dan sebagai pengacuan tanda-tanda bahasa pada hal-hal ekstralingual yang dibicarakan. Sedangkan Purwo (1990:16) mendefinisikan pragmatik sebagai telaah mengenai makna tuturan (utterance) yang terikat konteks.

Konsep pragmatik terkait penelitian ini, yaitu suatu kajian mengenai hubungan antara makna penggunaan bahasa dengan konteks dan situasi tutur. Konteks adalah bagian suatu uraian atau kalimat yang dapat 
mendukung atau menambah kejelasan makna (Pusat Bahasa, 2003:591). Yule (1996:87) membahas konteks ini dalam kaitannya dengan kemampuan seseorang untuk mengidentifikasi referen-referen yang bergantung pada satu atau lebih pemahaman orang itu terhadap ekspresi yang diacu. Parera (1990:120) mengemukakan tiga ciri yang harus dipenuhi untuk terciptanya suatu konteks, yaitu 1) setting, 2) kegiatan, dan 3) hubungan (relasi). Interaksi ketiganya membentuk konteks. Sedangkan situasi yang melahirkan sebuah tuturan adalah situasi tutur. Maksud sebuah tuturan yang sebenarnya dapat teridentifikasi melalui situasi tutur, yaitu penutur dan mitra tutur. Penutur adalah orang yang melakukan aktivitas tutur. Artinya, penutur merupakan orang yang sedang melakukan fungsi pragmatis tertentu di dalam komunikasi, baik komunikasi personal maupun komunikasi interpersonal. Adapun mitra tutur adalah orang yang menjadi objek pelaku sekaligus lawan tutur di dalam peristiwa komunikasi. Situasi tutur dapat menciptakan atau menghasilkan tindak tutur sebagai wujud verbal seseorang di saat mempengaruhi orang lain dalam berkomunikasi, yang tidak terbatas melalui tuturan lisan saja namun dapat terjadi pula pada tuturan tertulis. Berkenaan dengan situasi tutur dalam berkomunikasi, Sperber dan Wilson (dalam Rustono, 1999:34) berpendapat bahwa sebuah tindak tutur hendaknya mempertimbangkan lima aspek situasi tutur, yaitu (1) penutur dan mitra tutur, (2) konteks tuturan,
(3) tujuan tuturan, (4) tindak tutur sebagai bentuk tindakan atau aktivitas, dan (5) tuturan sebagai tindak verbal.

\section{Klasifikasi Tindak Tutur}

Tindak tutur adalah bagian dari pragmatik. Tindak tutur (istilah Kridalaksana 'pertuturan' / speech act, speech event), yaitu pengujaran kalimat untuk menyatakan agar suatu maksud dari pembicara diketahui pendengar (Kridalaksana, 1993:154). Tindak tutur adalah kegiatan seseorang menggunakan bahasa kepada mitra tutur dalam rangka mengkomunikasikan sesuatu. Makna yang dikomunikasikan tidak hanya dapat dipahami berdasarkan penggunaan bahasa dalam bertutur tersebut, tetapi juga ditentukan oleh aspek-aspek komunikasi secara komprehensif, termasuk aspek-aspek situasi komunikasi. Tindak tutur merupakan gejala individual yang bersifat psikologis dan keberlangsungan ditentukan oleh kemampuan bahasa si penutur dalam menghadapi situasi tertentu, sehingga dalam tindak tutur lebih dilihat pada makna atau arti tindakan dalam tuturannya (Chaer dalam Rohmadi, 2004:29).

Teori mengenai tindak tutur pertama kali dicetuskan oleh Austin, seorang filosof Inggris (1911-1960). Dalam bukunya How to Do Thing with Words (1962) ia mencetuskan teori tentang tindak tutur (Speech act Theory). Menurut Austin (dalam Rustono, 1999:39) ketika bertutur seseorang tidak hanya bertutur tapi juga melakukan sesuatu tindakan. Menurutnya, ada tiga tindakan 
yang dapat dilakukan melalui tuturan, yaitu lokusi (tindak tutur dalam mengucapkan atau menyatakan sesuatu), ilokusi (tindak tutur yang sekaligus melakukan suatu tindakan), dan perlokusi (tuturan yang memiliki efek atau daya yang ditimbulkan dari sebuah tuturan). Teori Austin kemudian mendapat kritik dari muridnya sendiri, yaitu Searle (1969). Menurut Searle (dalam Rustono, 1999:39-43) teori yang diajukan Austin terdapat hal yang membingungkan antara verbal dan tindakan, terlalu banyak tumpang tindih dalam teori, terlalu banyak heterogenitas dalam kategori, dan yang paling penting adalah tidak adanya prinsip klasifikasi yang konsisten. Selanjutnya Searle mengklasifikasikan tindak tutur menjadi lima kelompok, yaitu representatif, direktif, komisif, ekspresif, dan deklaratif.

Tindak tutur representatif adalah tindak tutur yang mengikat penuturnya akan kebenaran atas apa yang diujarkan. Jenis tindak tutur ini disebut juga tindak tutur asertif. Termasuk ke dalam jenis tindak tutur representatif adalah tuturan-tuturan yang menyatakan, menuntut, mengakui, melaporkan, menunjukkan, menyebutkan, memberikan kesaksian, berspekulasi dan sebagainya. Dalam tuturan itu, penutur bertanggung jawab atas kebenaran isi tuturannya. Tindak tutur direktif adalah tindak tutur yang dimaksudkan penuturnya agar mitra tutur melakukan tindakan yang disebutkan di dalam tuturan itu. Tuturan-tuturan memaksa, memohon, menyarankan, mengajak, meminta, menyuruh, menagih, mendesak, menyarankan, memerintah, memberi aba-aba dan menantang. Jenis tindak tutur ini disebut juga tindak tutur impositif. Tindak tutur ekspresif adalah tindak tutur yang dimaksudkan penuturnya agar ujarannya diartikan sebagai evaluasi tentang hal yang disebutkan di dalam tuturan itu. Tindak tutur ekspresif ini disebut juga sebagai tindak tutur evaluatif. Tuturan-tuturan memuji, mengucapkan terima kasih, mengkritik, mengeluh, menyalahkan, mengucapkan selamat, dan menyanjung. Tindak tutur komisif adalah tindak tutur yang mengikat penuturnya untuk melaksanakan apa yang disebutkan di dalam tuturannya. Berjanji, bersumpah, mengancam, menyatakan kesanggupan merupakan tuturan yang termasuk dalam jenis tindak komisif. Tindak tutur deklaratif adalah tindak tutur yang dimaksudkan penuturnya untuk menciptakan hal (status, keadaan, dan sebagainya) yang baru. Fraser (1978) menyebut tindak tutur ini dengan istilah establishive atau isbati. Tuturan-tuturan itu dengan maksud mengesahkan, memutuskan, membatalkan, melarang, mengizinkan, mengabulkan, mengangkat, menolong, mengampuni, memaafkan adalah termasuk dalam tindak tutur deklaratif.

\section{Prinsip Kerja Sama}

Kegiatan bertutur dapat berlangsung dengan baik apabila semua peserta pertuturan terlibat aktif dalam bertutur. Agar pesan dapat disampaikan dengan baik, maka komunikasi yang terjadi perlu mempertim- 
bangkan prinsip kerja sama. Sebab, dalam suatu pembicaraan, penutur dapat menyampaikan gagasannya seandainya mitra tuturnya bekerja sama. Hal ini sebagaimana rumusan prinsip kerja sama yang dikemukakan oleh Grice (1975:45), yang bunyinya sebagai berikut: Make your conversational contribution such as is required, at the stage at which it occurs, by the accepted purpose or direction of the talk exchange in which you are engaged ("Berikanlah kontribusi Anda dalam percakapan sesuai dengan kebutuhan, pada tingkat di mana percakapan tersebut berlangsung, sesuai dengan maksud dan tujuan di mana Anda terlibat"). Rumusan prinsip kerja sama tersebut (Yule, 2006:63-64; Nadar, 2009:24-25; Tarigan, 2009:35-36) dijabarkan ke dalam empat maksim, yaitu: 1) maksim kuantitas (maxim of quantity); 2) maksim kualitas (maxim of quality); 3) maksim relevansi (maxim of relevence); dan 4) maksim pelaksanaan (maxim of manner).

Dalam maksim kuantitas penutur diharapkan memberikan informasi yang cukup, relatif memadai dan seinformatif mungkin. Informasi tidak boleh melebihi informasi yang sebenarnya dibutuhkan mitra tutur. Pada maksim kualitas, seorang peserta tutur diharapkan dapat menyampaikan sesuatu yang nyata dan sesuai fakta yang sebenarnya di dalam bertutur. Di dalam maksim relevansi, dinyatakan bahwa agar terjadi kerja sama yang baik antara penutur dan mitra tutur, masing-masing hendaknya dapat memberikan kontribusi yang relevan tentang sesuatu yang dipertuturkan. Sedangkan maksim pelaksanaan mengharuskan peserta tutur bertutur secara langsung, jelas dan tidak kabur.

Analisis prinsip kerja sama dalam tindak tutur Nggahi Panati dalam prosesi lamaran pernikahan adat Bima merujuk pada teori Grice yang merumuskan prinsip kerja sama ke dalam empat maksim, yaitu maksim kuantitas, maksim kualitas, maksim relevansi, dan maksim pelaksanaan. Pertimbangan penggunaan teori kerja sama Grice dalam kajian tindak tutur Nggahi Panati dalam prosesi lamaran pernikahan adat Bima ini didasarkan bahwa di dalam peristiwa tutur tersebut terkandung bidal atau maksim kuantitas, kualitas, relevansi, dan pelaksanaan.

\section{Prinsip kesantunan}

Prinsip kesantunan berkenaan dengan aturan tentang hal-hal yang bersifat sosial, estetis dan moral di dalam bertindak tutur (Grice,1991:308). Alasan dicetuskannya prinsip kesantunan adalah bahwa di dalam tuturan, penutur tidak cukup hanya mematuhi prinsip kerja sama. Prinsip kesantunan diperlukan untuk memenuhi prinsip kerja sama dan mengatasi masalah yang timbul akibat penerapan prinsip kerja sama. Prinsip kesantunan ini menurut Wijana (1996:55) berhubungan dengan dua peserta percakapan, yaitu diri sendiri (self) dan orang lain (other); diri sendiri adalah penutur dan orang lain adalah lawan tutur serta 
orang ketiga yang dibicarakan penutur dan lawan tutur.

Skala pengukuran kesantunan yang banyak digunakan sebagai dasar acuan dalam penelitian kesantunan (Tarigan, 2009:4453; Nadar, 2009:28-51) ada tiga macam, yaitu (1) skala kesantunan menurut Leech (1983), (2) skala kesantunan menurut Brown dan Levinson (1978), dan (3) skala kesantunan menurut Lakoff (1973). Skala kesantunan Leech (1983), mengemukakan setiap bidal interpersonal itu dapat dimanfaatkan untuk menentukan peringkat kesantunan menurut tuturan, yaitu (1) skala untung rugi (cost-benefit scale); (2) skala pilihan (optionaly scale); (3) skala ketidaklangsungan (indirectness scale); (4) skala keotoritasan status sosial (authority scale), dan (5) skala jarak sosial (social distance scale). Pada kesantunan Brown dan Levinson (1978) terdapat tiga skala penentu tinggi rendahnya peringkat kesantunan sebuah tuturan. Ketiga skala tersebut, yaitu (1) peringkat sosial, (2) peringkat kekuasaan, dan (3) peringkat kultural. Sedangkan skala kesantunan Lakoff (1973) menyatakan tiga ketentuan untuk dapat dipenuhinya kesantunan di dalam kegiatan bertutur, yaitu (1) skala formalitas (formality scale), (2) skala ketidaktegasan (hesitancy scale), (3) skala kesamaan atau kesekawanan (equelity scale).

Skala kesantunan Lakoff menjadi rujukan dalam kajian tindak tutur Nggahi Panati dalam prosesi lamaran pernikahan adat Bima ini. Hal yang menjadi pertim- bangan penggunaan skala kesantunan Lakoff ini dibanding skala kesantunan Leech atau skala kesantunan Brown dan Levinson adalah karena aturan-aturan kesantunan yang terkandung dalam tindak tutur Nggahi Panati sesuai dengan skala kesantunan Lakoff. Kesantunan dalam tindak tutur Nggahi Panati dideskripsikan melalui pernyataan yang tidak memaksa dan tidak terkesan angkuh, pilihan-pilihan dalam bertutur harus membuat rasa nyaman lawan tutur, dan menunjukan keramahan dan persahabatan melalui tuturan.

\section{PEMBAHASAN}

Hasil penelitian tentang Nggahi Panati dalam prosesi lamaran pernikahan adat $\mathrm{Bi}$ ma yang dilakukan melalui wawancara dengan beberapa informan menunjukkan bahwa Nggahi Panati dalam prosesi lamaran pernikahan adat Bima terdiri atas dua bentuk, yang merupakan tahapan dalam prosesi lamaran pernikahan adat Bima. Kedua bentuk itu adalah bentuk $W{ }^{\prime}{ }^{\prime} i$ Nggahi atau Pita Nggahi dan bentuk Oto Co'i dan Tarima Co'i.

Pada bentuk Wi'i Nggahi atau Pita Nggahi pihak laki-laki yang akan pergi melamar ke pihak wanita terlebih dahulu mengadakan pertemuan antara keluarga dekat yang disebut Mbolo Weki untuk membicarakan rencana pelamaran ke pihak wanita. Pertemuan tersebut bersifat rahasia guna menghindari hal-hal yang dapat menggagalkan rencana pelamaran atau rencana pernikahan. Isi pembicaraan dalam per- 
temuan tersebut menyangkut niat dan hajat tuan rumah yang ingin menikahkan anaknya yang disampaikan kepada sanak keluarga yang hadir dalam pertemuan itu. Selanjutnya, dibahas rencana waktu yang tepat untuk pergi ke kediaman bakal calon mempelai wanita guna menanyakan statusnya (apakah masih sendiri atau sudah ada yang melamarnya). Tahap ini dalam tradisi lamaran pernikahan adat Bima disebut Lao Sodi Ntaru. Dalam pembahasan rencana Lao Sodi Ntaru ini ditentukan pula siapa yang akan menjadi delegasi keluarga sebagai juru lamar atau disebut Ompu Panati. Ompu Panati biasanya ditunjuk dari tokoh masyarakat yang memiliki pengetahuan kebahasaan yang memadai, baik dari segi penggunaan varuasi bahasa, penguasaan ungkapan, maupun kemampuan dalam berpantun. Selain itu, yang dipilih dan ditunjuk sebagai Ompu Panati adalah orang yang memiliki pengalaman dalam hal melamar.

Pada tahap Lao Sodi Ntaru kepada pihak wanita akan diperoleh jawaban 'masih lowong' atau 'sudah ada yang menandainya'. Bila jawaban dari pihak wanita mengatakan bahwa 'sudah ada yang menandainya', maka proses lamaran berakhir pada tahap Lao Sodi Ntaru. Tetapi, bila jawaban yang disampaikan oleh pihak wanita adalah 'masih lowong', maka proses lamaran berlanjut ke tahap Wi'i Nggahi atau Pita Nggahi. Wi'i Nggahi atau Pita Nggahi adalah proses lamaran pihak laki-laki kepada pihak wanita dengan menggunakan tindak tutur. Dalam proses ini antara delegasi pihak laki-laki dan pihak wanita melakukan pembicaraan tentang profil calon pengantin yang akan dinikahkan dan tentang kesanggupan mahar pernikahan yang harus disediakan oleh pihak laki-laki. Peran tindak tutur penutur dan mitra tutur dalam peristiwa tutur ini dapat menghasilkan kesepakatan bersama.

Peristiwa tindak tutur Nggahi Panati pada bentuk Wi'i Nggahi atau Pita Nggahi berdasarkan hasil observasi dan rekam serta hasil catat dan simak dilakukan oleh dua delegasi, yaitu delegasi pihak laki-laki yang terdiri dari Ompu Panati yang didampingi oleh beberapa orang keluarga pihak lakilaki dan delegasi pihak wanita yang terdiri dari dua orang penerima lamaran didampingi oleh kedua orangtua calon pengantin wanita. Konteks tuturan terjadi di kediaman orangtua calon pengantin wanita, bertempat di ruang tamu berukuran cukup luas dengan kursi tamu dari sofa dan beberapa kursi dari bahan plastik. Saat peristiwa tindak tutur terjadi pada hari Minggu malam, jam 19.20 Wita. Hubungan antara penutur dan mitra saling kenal sebelumnya sehingga tercipta suasana yang akrab dan santai. Tidak terlihat ekspresi ketegangan di raut wajah yang hadir pada pertemuan malam itu. Pembicaraan dimulai dengan menanyakan khabar dan keadaan masing-masing. Selanjutnya, peristiwa tindak tutur Nggahi Panati dimulai dari delegasi pihak wanita menanyakan maksud kedatangan delegasi pihak laki-laki. Ompu Panati sebagai juru 
lamar pihak laki-laki menyampaikan maksud kedatangannya. Kesan, perasaan, tanggapan dan persepsi penutur dan mitra tutur saling bermunculan dalam peristiwa tutur tersebut. Bahasa Bima yang digunakan oleh penutur dan mitra tutur menggunakan variasi bahasa tinggi dan bahasa rendah. Penggunaan Patu atau pantun, ungkapan atau idiom, dan bahasa metafora mendominasi peristiwa tindak tutur tersebut. Pada akhir pembicaraan terjadi kesepakatan antara penutur dan mitra tutur sehingga tujuan tuturan pun tercapai, yaitu lamaran diterima dan disepakati rencana pernikahan.

Setelah melalui tahap Wi'i Nggahi atau Pita Nggahi, maka tahap Nggahi Panati selanjutnya adalah bentuk Oto Co'i dan Tarima Co'i. Bentuk Nggahi Panati ini adalah bahasa pengantaran mahar dan penerimaan mahar. Bentuk ini merupakan bentuk tindak tutur karena ada tindak tutur penutur, yaitu kata-kata pengantaran mahar dari Ompu Panati dan ada tindak tutur dari mitra tutur yakni kata-kata penerimaan mahar dari pihak wanita. Bahasa yang digunakan pada tindak tutur ini dituturkan dengan cara berpantun.

\section{Kebermaknaan Tindak Tutur Nggahi Panati dalam Prosesi Lamaran Per- nikahan Adat Bima}

Kebermaknaan diartikan memiliki makna beserta fungsi-fungsi komunikatif. Makna yang terkandung dalam tindak tutur Nggahi Panati dalam prosesi lamaran pernikahan adat Bima memiliki fungsi-fungsi komunikasi, seperti bentuk pernyataan yang kategorinya diklasifikasikan, maksim kerja sama, dan skala kesantunan.

\section{Klasifikasi tindak tutur dalam tindak tu- tur Nggahi Panati}

Sebagaimana teori klasifikasi tindak tutur yang dikemukakan Searle (1969), maka tindak tutur Nggahi Panati dalam prosesi lamaran pernikahan adat Bima terdiri atas tindak tutur representatif, direktif, komisif, ekspresif, dan deklaratif.

\section{Tindak tutur representatif}

Tindak tutur representatif adalah tindak tutur yang mengikat penuturnya akan kebenaran atas apa yang diujarkan. Jenis tindak tutur ini disebut juga tindak tutur asertif. Termasuk ke dalam jenis tindak tutur representatif adalah tuturan-tuturan yang menyatakan, menuntut, mengakui, melaporkan, menunjukkan, menyebutkan, memberikan kesaksian, berspekulasi dan sebagainya. Dalam tindak tutur Nggahi Panati terdapat tuturan-tuturan menyatakan, menyebutkan, dan melaporkan.

1) Tuturan menyatakan

a) Mada doho ma mai raka sowo ita doho dou ta siwe. $\underline{B}$ a ne'e mai katada isi ade tando ita doho sa'udu. Ina mpu'u walina $\underline{b}$ a ne'e lu'u dei ade ra loko ita doho. (Kami datang hendak bernaung di bawah keteduhan hati tuan-tuan di pihak wanita. Ingin menyampaikan isi hati pada tuan-tuan sekalian. Yaitu keinginan untuk ma- 
suk mendiami hati dan perut tuantuan).

Pernyataan di atas adalah bentuk tuturan menyatakan lamaran kepada pihak wanita. Kategori representatif ini mengandung makna kebenaran atas tindakan yang dilakukan.

b) Mada doho mamai bane'e nuntu kamoci ro kamaoi. Nuntu ro nggahi, nonta ne'e kanggihi. (Kami datang untuk menyampaikan suatu maksud. Membicarakan tentang keinginan untuk berladang).

Pernyataan di atas mengandung makna komunikatif bahwa penutur menyatakan suatu keinginan kepada mitra tutur.

\section{2) Tuturan menyebutkan}

a) Waraku anana La Heso ma ne'e kadeni weki la'o ana siwe ndai Baba Hawa mangara La Hafsah. (Adalah anaknya La Heso ingin mendekatkan diri dengan anak gadis Baba Hawa yang bernama La Hafsah).

Pernyataan di atas menyebutkan nama sorang laki-laki yang ingin melamar seorang gadis. Makna tindak tutur ini adalah menyebutkan atas kebenaran yang diujarkan untuk diketahui oleh mitra tutur.

b) Tundu ra lembaku ma saraka kani ra lombo. Jima ra kondo ma saraka jungge konde. Kariro ra sinci diampa kaiku sonco. Wa'a kaiku marakani maniki basupu ne'e nika. ((Kami pikul seluruh perlengkapan pakaian. Gelang dan cincin yang berkilau. Bumbu dapur yang lengkap karena hendak kaawin).

Pernyataan di atas menyebutkan mahar yang dibawa oleh pihak calon pengantin laki-laki. Tindak tutur menyebutkan ini bermakna pemberitahuan kepada mitra tutur agar dapat diketahui dan diterima.

3) Tuturan melaporkan

a) Ake mada doho mamai wa'a ro katadaku nggahi ra eli ade wura ma ulu. Mai kapahuku samenana mpama ra pehe. Wa'a ro teweku ma saraka isi tewu. Bongina ma saroa banga, ma saraka uta ra opu ma mboto apa. (Kini kami datang untuk memperkuat ikatan yang telah terjalin sebulan yang lalu. Mewujudkan segala apa yang pernah dibicarakan. Membawa segala keinginan yang diputuskan. Beras dalam belanga besar dan daging yang gemuk dan penuh lemak).

Pernyataan di atas bentuk tindak tutur melaporkan suatu keadaan yang baru dari hubungan yang telah terjalin.

b) Watira wara diparesa ro tio ba mada doho samenana isi tau. Nawa'ura ncihi ncao samenana ratiwi ro wa'a ba ndai oтрu ra wa'i. (Sudah tidak ada lagi yang perlu diperiksa segala yang dibawa. Semuanya telah jelas dan lengkap).

Pernyataan di atas menunjukkan tuturan yang diujarkan bermakna melaporkan kembali bahwa apa yang telah diserahkan oleh pihak laki-laki diterima oleh pihak perempuan. 
II. Tindak tutur direktif

Tindak tutur direktif adalah tindak tutur yang dimaksudkan penuturnya agar mitra tutur melakukan tindakan yang disebutkan di dalam tuturan itu. Tuturan-tuturan memaksa, memohon, menyarankan, mengajak, meminta, menyuruh, menagih, mendesak, menyarankan, memerintah, memberi abaaba dan menantang termasuk ke dalam jenis tindak tutur direktif ini. Jenis tindak tutur ini disebut juga tindak tutur impositif. Dalam tindak tutur Nggahi Panati terdapat tuturan-tuturan memohon, meminta, dan mengajak.

a) Tuturan memohon

Santikana warampa nggahi ra eli mada doho ma loa lu'u, tanda warana wua ra wuri ndi dula labo. (Jika maksud kami bisa diterima, maka kami berharap mendapat jawaban sebagai oleh-oleh untuk dibawa pulang).

\section{b) Tuturan meminta}

kaliri ro kahampa to'ipu so ra sera di ne'e kaita ngguda kai sura. (ladang yang manakah yang ingin tuan garap?)

\section{c) Tuturan mengajak}

Tahantaku rima raho pamao di ndai ruma. Mori sena to ’ina La Heso labo La Hafsah ma sanai-nai. (Mari kita tengadahkan tangan kehadirat Sang Pencipta. Semoga kehidupan La Heso dengan La Hafsah bahagia sepanjang hari).

\section{III.Tindak tutur komisif}

Tindak tutur komisif adalah tindak tutur yang mengikat penuturnya untuk melaksanakan apa yang disebutkan di dalam tuturannya. Berjanji, bersumpah, mengancam, menyatakan kesanggupan merupakan tuturan yang termasuk dalam jenis tindak komisif. Dalam tindak tutur Nggahi Panati terdapat tuturan-tuturan berjanji dan menyatakan kesanggupan.

a) Tuturan berjanji

Napodasi ntaru liri mai ntiri ake, mada doho matoho nggahi diru'u mai mbali. (Jika memang benar lowong sebagaimana harapan kedatangan kami ini, maka kami berjanji untuk datang kembali).

\section{b) Tuturan menyatakan kesanggupan}

Bune santika do'ona nasi mangemo, na ntene mbalina di sobu. Ndede walimpa mpama ra pehe, mada doho ma kapahu. (sebagaimana halnya burung yang terbang jauh, pasti akan kembali juga di sarangnya. Begitu pula halnya dengan pembicaraan kita, kami akan mewujudkannya).

\section{IV.Tindak tutur ekspresif}

Tindak tutur ekspresif adalah tindak tutur yang dimaksudkan penuturnya agar ujarannya diartikan sebagai evaluasi tentang hal yang disebutkan di dalam tuturan itu. Tindak tutur ekspresif ini disebut juga sebagai tindak tutur evaluatif. Tuturan-tuturan memuji, mengucapkan terima kasih, mengkritik, mengeluh, menyalahkan, men- 
gucapkan selamat, menyanjung adalah termasuk dalam tindak tutur ekspresif. Dalam tindak tutur Nggahi Panati terdapat tuturantuturan memuji, menyanjung, dan berterima kasih.

\section{a) Tuturan memuji}

Ntika pahuna ro taho ruku rawi ndi nuntu ba dou ma riwu. (Cantik parasnya dan baik perilakunya menjadi pembicaraan orang banyak).

\section{b) Tuturan menyanjung}

Ade mada midi tanda cua samada. Kawara si la were ma maci sarome bune wua sarume. Ncoki ja ra iuna ade ma sabala ai. Ba da loana maru sabala ai ma more. (Hati resah memendam rindu. Jika teringat pujaan hati yang tersenyum manis. Sepanjang malam selalu terbayang. Hingga mata tak dapat terpejam).

\section{c) Tuturan berterima kasih}

Tarima kasi la mada doho di ita doho kaso. Watija du warana di maja ra jule ba supu loana lu'u mada doho ade loko Baba Hawa. (Terima kasih kami sampaikan kehadapan tuan-tuan sekalian. Kami sudah tidak merasa malu dan ragu lagi karena sudah diterima oleh Baba Hawa).

\section{Tindak tutur deklaratif}

Tindak tutur deklaratif adalah tindak tutur yang dimaksudkan penuturnya untuk menciptakan hal (status, keadaan, dan sebagainya) yang baru. Tuturan-tuturan itu dengan maksud mengesahkan, memutuskan, membatalkan, melarang, mengizinkan, mengabulkan, mengangkat, menolong, mengampuni, memaafkan adalah termasuk dalam tindak tutur deklaratif. Dalam tindak tutur Nggahi Panati terdapat tuturan-tuturan mengabulkan dan memutuskan.

a) Tuturan mengabulkan

Santikana ndedempa ranuntu ro nggahi ita doho sa'udu ndonta ma ne'e kanggihi, kaliri ro kahampa to'ipu so ra sera di ne'e kaita ngguda kai sura. Warakura dinenti nuntu ndai Ompu Panati. (Jika demikian keinginan tuan-tuan untuk berladang, ladang yang manakah yang ingin tuan garap? Agar menjadi pegangan dari pembicaraan kita Ompu Panati).

b) Tuturan memutuskan

Nggara ndedesi nia ra naja ita doho dou ta mone, au walipu warana nia ra ne'e ta ma kacampo mu'u. Mada doho di makalu'una di ade nia ro naja ndai sa'udu. (Jika demikian niat dan hajat tuan-tuan, apalagi niat dan hajat untuk menjalin tali kekeluargaan. Kami terima niat dan hajat tuan-tuan sebagai niat dan hajat kita bersama).

Prinsip kerja sama dalam tindak tutur Nggahi Panati

a) Maksim kuantitas

Dalam maksim kuantitas penutur diharapkan memberikan informasi yang cukup, relatif memadai dan seinformatif 
mungkin. Informasi tidak boleh melebihi informasi yang sebenarnya yang dibutuhkan mitra tutur. Dalam tindak tutur Nggahi Panati maksim kuantitas dideskripsikan melalui pernyataan berikut ini.

Waraku anana La Heso ma ne'e kadeni weki la'o ana siwe ndai Baba Hawa mangara La Hafsah. (Adalah anaknya La Heso ingin mendekatkan diri dengan anak gadis Baba Hawa yang bernama $\mathrm{La}$ Hafsah).

b) Maksim kualitas

Pada maksim kualitas, peserta tutur diharapkan dapat menyampaikan sesuatu yang nyata dan sesuai fakta yang sebenarnya di dalam bertutur. Maksim ini dalam tindak tutur Nggahi Panati dideskripsikan melalui pernyataan sebagai berikut.

Ake mada doho mamai wa'a ro katadaku nggahi ra eli ade wura ma ulu. Mai kapahuku samenana mpama ra pehe. Wa'a ro teweku ma saraka isi tewu. (Kini kami datang untuk memperkuat ikatan yang telah terjalin sebulan yang lalu. Mewujudkan segala apa yang pernah dibicarakan. Membawa segala keinginan yang diputuskan)

c) Maksim relevansi

Dalam maksim relevansi, dinyatakan bahwa agar terjadi kerja sama yang baik antara penutur dan mitra tutur, masingmasing hendaknya dapat memberikan kontribusi yang relevan tentang sesuatu yang dipertuturkan. Maksim relevansi ini dalam tindak tutur Nggahi Panati dideskripsikan melalui pernyataan berikut ini.

Nggara ndedesi nia ra naja ita doho dou ta mone, au walipu warana nia ra ne'e ta ma kacampo mu'u. Mada doho di makalu'una di ade nia ro naja ndai sa'udu. (Jika demikian niat dan hajat tuan-tuan, apalagi niat dan hajat untuk menjalin tali kekeluargaan. Kami terima niat dan hajat tuan-tuan sebagai niat dan hajat kita bersama).

\section{d) Maksim pelaksanaan}

Maksim pelaksanaan mengharuskan peserta tutur bertutur secara langsung, jelas dan tidak kabur. Dalam tindak tutur Nggahi Panati maksim pelaksanaan dideskripsikan melalui pernyataan sebagai berikut.

Warakai ndiha ro nggari mai mada doho, ne'e karongga isi ade ndai Ompu Bedo. (Adapun kedatangan kami ini untuk menyampaikan isi hati Ompu Bedo).

\section{Prinsip kesantunan dalam tindak tutur Nggahi Panati}

a) Skala formalitas

Skala formalitas yakni skala yang dinyatakan bahwa agar para peserta tutur dapat merasa nyaman dalam kegiatan bertutur. Tuturan yang digunakan tidak boleh bernada memaksa dan tidak boleh terkesan angkuh. Jarak formalitas harus selalu dijaga dengan sewajarnya tanpa ada kesan dibuatbuat. Dalam tindak tutur Nggahi Panati skala formalitas ditunjukkan melalui pernyatan 
berikut ini.

Mboto-mboto kangampu ade ndiha ra nggari kai mai ake. Mada doho ma mai raka sowo ita doho dou ta siwe. $\underline{B}$ a ne'e mai katada isi ade tando ita doho sa'udu. Ina mpu'u walina $\underline{b} a$ ne'e lu'u dei ade ra loko ita doho. (Mohon dimaafkan atas kedatangan kami ini. Kami datang hendak bernaung di bawah keteduhan hati tuan-tuan di pihak wanita. Ingin menyampaikan isi hati pada tuan-tuan sekalian. Yaitu keinginan untuk masuk mendiami hati dan perut tuan-tuan).

\section{b) Skala ketidaktegasan}

Skala ketidaktegasan, yaitu kegiatan bertutur antara penutur dan mitra tutur dapat saling merasa nyaman dengan pilihanpilihan dalam bertutur harus diberikan oleh kedua belah pihak, dengan tujuan menciptakan suasana santun agar tidak tercipta suasana tegang. Suasana tegang akan dianggap kurang santun karena komunikasi tidak berjalan sebagaimana layaknya. Skala ketidaktegasan dalam tindak tutur Nggahi Panati dideskripsikan melalui pernyataan sebagai berikut.

Mada doho mamai bane'e nuntu kamoci ro kamaoi. Nuntu ro nggahi, nonta ne'e kanggihi. Ne'e kanggihi ro kanggama bune rarawi ba dou mariwu. (Kami datang untuk menyampaikan suatu maksud. Membicarakan tentang keinginan untuk berladang. Berladang sebagaimana yang dihajatkan banyak orang). c) Skala kesekawanan

Skala kesekawanan yakni peringkat kesekawanan atau kesamaan yang menunjukkan bahwa agar dapat bersifat wajar. Seseorang haruslah bersikap ramah dan selalu mempertahankan persahabatan antara pihak yang satu dengan pihak yang lain. Agar tercapai maksud yang demikian, penutur haruslah dapat menganggap mitra tutur sebagai sahabat. Dengan menganggap pihak yang satu sebagai sahabat baik dengan pihak lainnya, maka rasa kesekawanan dan kesejajaran sebagai salah satu prasyarat kesantunan akan dapat tercapai. Skala kesekawanan dalam tindak tutur Nggahi Panati dideskripsikan melalui pernyataan berikut ini.

aTarima kasi la mada di samenana ita doho kaso. Watipu rakaku kira ade wara kai mai kakaro. Ta katadapu isi ade di tando mada doho sa'udu. Aina maja ra jule, ta karonggampa aina kahampa. (Terima kasih kami sampaikan kehadapan tuan-tuan. Belumlah dapat kami kira akan maksud kedatangan tuan-tuan. Bukalah isi hati tuan-tuan di hadapan kami. Janganlah malu dan ragu, mohon sampaikan saja jangan ada pembatas).

b

cImplikasi Kajian Tindak Tutur Nggahi Panati dalam Prosesi Lamaran Pernikahan Adat Bima terhadap Pembelajaran Muatan Lokal Bahasa Daerah di Sekolah

dHasil penelitian ini direkomendasikan kepada pemerintah daerah Kota dan Kabu- 
paten Bima untuk dimasukan dalam struktur kurikulum di setiap satuan pendidikan pada mata pelajaran bahasa daerah sebagai salah satu muatan lokal dalam struktur kurikulum di sekolah sebagaimana pada kurikulum KTSP. Tujuan yang diharapkan dari hasil penelitian ini diimplikasikan ke dalam pembelajaran muatan lokal bahasa daerah di sekolah adalah dapat bermanfaat bagi siswa baik dari aspek pengetahuan kebahasaan maupun aspek pembentukan kepribadian siswa dan penanaman nilai-nilai luhur budaya Bima.

eHasil kajian tindak tutur Nggahi Panati dalam prosesi lamaran pernikahan adat Bima ini akan diimplikasikan dalam materi pembelajaran:

$\mathrm{f}$

a) percakapan (strategi dalam melakukan tindak tutur);

b) berkomunikasi (kerja sama dalam tindak tutur);

c) sopan santun (kesantunan berbahasa);

d) penggunaan bahasa (kaidah penggunaan idiom atau ungkapan pada variasi bahasa Bima yang digunakan penuturnya); dan

e) nilai-nilai budaya (penanaman nilai-nilai budaya Bima guna pembentukan kepribadian siswa serta sebagai upaya proteksi dari pengaruh negatif budaya luar).

\section{SIMPULAN}

Nggahi Panati dalam prosesi lamaran pernikahan adat Bima terdiri atas dua bentuk, yang merupakan tahapan dalam prosesi lamaran pernikahan adat Bima. Kedua bentuk itu adalah bentuk Wi'i Nggahi atau Pita Nggahi dan bentuk Oto Co'i dan Tarima Co'i. Terdapat prosesi lain dalam prosesi lamaran pernikahan adat Bima, yaitu prosesi Lao Sodi Ntaru. Prosesi ini dilakukan oleh pihak laki-laki dalam hal menanyakan status calon mempelai wanita yang akan dilamar. Dalam prosesi ini terjadi pembicaraan yang menggunakan tindak tutur.

Kebermaknaan tindak tutur Nggahi Panati dalam prosesi lamaran pernikahan adat Bima memiliki makna dan fungsi-fungsi komunikasi yang terkandung dalam bentuk tindak tutur Nggahi Panati itu sendiri. Bentuk tindak tutur tersebut diklasifikasikan melalui kategori representatif, direktif, komisif, ekspresif, dan deklaratif. Fungsifungsi komunikasi lain dalam tindak tutur Nggahi Panati juga terkandung dalam prinsip kerja sama yang dijabarkan melalui maksin kuantitas, maksim kualitas, maksim relevansi, dan maksim pelaksanaan. Fungsifungsi komunikasi yang lain dalam tindak tutur Nggahi Panati dideskripsikan melalui prinsip kesantunan dengan menggunakan skala formalitas, skala ketidaktegasan, dan skala kesekawanan.

\section{UCAPAN TERIMA KASIH}

Penulis mengucapkan terima kasih kepada mitra bestari atas kritikan dan masukan yang membangun untuk perbaikan artikel ini. 
DAFTAR PUSTAKA

Chaer, A. 2003. Linguistik Umum. Jakarta: PT. Rineka Cipta.

Leech, G. 1993. Prinsip-prinsip Pragmatik. Diterjemahkan oleh M.D.D. Oka; pendamping Setyadi Setyapratama. Jakarta: Penerbit Universitas Indonesia (UI-Press).

Levinson, S.C. 1983. Pragmatics. Cambridge: Cambridge UnivercityPress.
Nababan, P.W.J. 1987. Ilmu Pragmatik: Teori dan Penerapannya. Jakarta: Depdikbud.

Oktavianus, 2006. Analisis Wacana Lintas Bahasa. Padang: Andalas University Press.

Sudaryanto, dkk. 1990. Aneka Konsep Kedataan Lingual dalam Linguistik. Yogyakarta: Duta Wacana University Press. 